\title{
日本語教科書にみる多義動詞「きく」 \\ 一中国語母語話者による語義判断に着目してー \\ The Polysemic Verb “Kiku” in Japanese Texts: \\ Focusing on Word Sense Disambiguation by Native Chinese Speakers
}

\section{蔡 欣吟}

\section{淡江大学}

\section{要旨}

日本語学習者にとって、多義語の語義判断は容易にできることではない。実際に 教育現場に活用できる語義判断の手がかりを提示することを、本稿の目的とする。 台湾で使用されている教科書を調査資料に、多義動詞「きく」の導入過程と使用例を 観察した。意味の判断に戸惑う原因は、日本語における語義の上位概念は一つである のに対し、中国語ではそれは別々の語で表されるため、それらの上位概念が日本語と 共通していないことにあると推定する。この問題を解決するために、動作の自発性と 積極性に着目した。「きく」の使用例を文脈依存型と共起関係依存型に分類し、考察 した結果、自発性と積極性によって、それに相応する語義を選択することが妥当で あることが認められる。この調査結果は学習者に、より豊富な選択の仕方を提供 できると考える。

キーワード :

中国語母語話者、教科書、多義語、聞く、語義判断 


\section{日本語教科書にみる多義動詞「きく」 \\ 一中国語母語話者による語義判断に着目してー}

\section{蔡 欣吟 \\ 淡江大学}

\section{1.はじめに}

日本語の多義語研究はその語義の特徵や構造を中心に研究されてきた。近年では、 認知言語学の観点から分析・研究がなされ、数多くの成果が挙げられている。そして、 日本語教育の分野においては、これらの研究成果を応用し、多義語の習得に役立てて いる。これらの研究が盛んに行われていることにより、日本語教育の現場においては、

多義語を理解語彙から使用語彙へと移行させやすくなってきている。しかし、その 一方で、習得した多義語の使用には問題がないが、文中における正しい意味を読み 取ることには支障が生じてしまうという現象も見られる。本稿では、このような事例 の中でも、意味の判断に戸惑うことが目立つと考えられる、多義語「きく」を研究対象 とする。

中国語を母語とする日本語学習者は、学習過程において漢字の知識を活用し、学習 に役立てていることが指摘されている1。本稿の研究対象である動詞「きく」は、日本語 における一般の使用では複数の漢字表記が許容される。音を耳で感じ取り、また、 自然に耳に入ってくる場合は「聞」く、注意して聞く場合は「聴」く、尋ねる、答えを 求める、問う場合は「訊」くと、若干ゆれがあるとしても、辞書に立項されており、 意味によって漢字表記の使い分けが認められていると考えられる。しかし、日本語 教育の教科書では、上記三つの意味の「きく」はすべて「聞」で表記されていることが ほとんどである。このような状況では、中国語を母語とする日本語学習の初心者は、 漢字の知識を利用し、複数の意味から正しい、もしくは文の解釈にふさわしい意味を 選択することができなくなる。学習の段階において、漢字表記に頼ることなく、 正しい意味を選択するには、どのような手がかりが考えられるのだろうか。本稿では、 台湾で使用されている初・中級教科書における多義語「きく」の使用例を調査し、学習 過程において、インプットされ、蓄積した言語知識はどのようなもので、多義語の 意味の判断にさらに必要なものは何なのかを分析する。これにより、初・中級の段階 において学習者に多義語「きく」の意味選択の仕方や学習方法をどのように指導して いけば良いか考えることを、本稿の目的とする。

1 漢字語圈の学習者にとっては、漢字の意味や字形の相違点や類似点が習得上の障害になって いることがあるが、非漢字語圈の学習者より有利である、ということについては茅本 (2000)、 宮岡 (2005)、中西(2010)などが言及した。 


\section{2. 先行研究}

現代語における「聞く」に関しては、森田(1979)では意味用法が簡潔にまとめられて いる。「聞く」本来の意味は、音や声など聴覚的なものを耳で捉えることである。 意識を伴わない感覚的な現象から、音や声を受容しようとする積極的な行為へと 発展する。そこからさらに、積極的に尋ねる行為も「聞く」であることになっていると 述べられている。なお、森田（1979）では、耳で音や声を受け取る行為の「聞く」と、 効果が表れる「効く」や「口を利く」を、同音異義語として取り扱っている。

邱 (2006) では、認知言語学の視点から多義語「聞く」の生成メカニズムを検討して いる。さらに、中国語母語話者の観点に立ち、多義拡張と漢字表記との関わりも考察 している。「聴」・「訊」・「利」・「効」という漢字が用いられる場合、「聞」に書き換え られることが見られる。これは、「聞く」は基本義としての「音を聴覚器官で感じ取る」 という意味から、他の「きく」に拡張されるため、「聴」・「訊」・「利」・「効」に書き換え られると指摘されている。

日本語教育の立場から、多義語の使用はどのような様相を呈しているかについて、 熟見(2015)では KY コーパスを利用し、中国語を母語をする日本語学習者による多義 動詞の使用実態を調査している。対象とする動詞は「ミル」「ツクル」「ル」「カケル」 「カカル」「ヒク」である。これらの動詞は中国語話者 30 名によって、どのような語義が 使用されているのかを調査した。その結果、使用頻度の高い語は使用語義の広がりが 見られるのに対して、相対的に使用頻度の低い語は使用語義の広がりが見られない ことがわかった。また、語彙習得については、かつては知識の量的側面が重視されて いたが、最近は質的側面の重要性に対する認識が高まっていることに言及している。

\section{3. 調査対象および調查資料}

本稿は、動詞「きく」を調査対象とする。本稿における「きく」の多義性の認定について、 簡単に述べておく。国広 (1982) では、「同一の音形によって表される複数の意味が、 意味的に関連を持たない場合を『同音異義語』、意味的に関連を持つ場合を『多義語』」 であるとしている。しかし、一つの語が多義語なのか、同音異義語なのか、その区別 の仕方が困難であり、また、意味的関連が簡単に線引きできない語彙も存在する。 山崎 (2006) では、辞書編纂の際に、見出し語の認定はどの程度の細かさで分けるのか、 統一して扱うことが難しいと述べられている。本稿の調査対象である「きく」について、 国語辞典における扱われ方を見る。『日本国語大辞典』第二版では、動詞「きく」は二つ 立項されており、漢字表記で示すと、「利・効」と「聞・聴」があり、別項で扱われて いることが見られる。その一方で、『日本語多義語学習辞典 動詞編』(森山、2012）では、 「きく」が立項されており、同音の動詞が一つにまとめられていることが見られる。 
日本語教育においては、「きく」を多義語として扱うことが認められている。本稿では、 日本語教育の立場から森山（2012）に従い、「きく」を多義語と見なす。語義を限定せず、 調查資料における「きく」を全数調查し、教科書における「きく」の使用について見る。

「きく」は、日本語能力試験 (JLPT)のもっとも簡単なレベル2、つまり、基本的な 日本語を理解寸るための語に認定されている。基本語彙の習得過程について見る ために、調査資料として初・中級の教科書を用いることにする。本稿は、筆者が勤務 する大学をはじめ、台湾の高等教育機関で初・中級日本語教材として用いられている 5 種類の教科書を調查資料と寸る。具体的には以下の表 1 のとおりである。各資料に ア〜オの記号を付し、以降は記号で資料を示寸。アとイは初級、ウとエは初級と中級、 オは中級の段階で、それぞれ用いられているものである。

\section{表 $1 ：$ 調査資料一覧}

\begin{tabular}{|c|c|c|}
\hline 記号 & 日本語書名 & 中国語書名 \\
\hline ア & （新）文化初級日本語 I 、II & 新文化日本語初級 1～4 \\
\hline 1 & 文化初級日本語テキスト改訂版 I、II & 文化初級日本語改訂版 1～4 \\
\hline ウ & $\begin{array}{l}\text { 学ぼう！日本語初級 I } \\
\text { 学ぼう！日本語初級 II }\end{array}$ & $\begin{array}{l}\text { 來學日本語基礎 } 1 、 2 \\
\text { 來學日本語基礎進階 } 1 、 2\end{array}$ \\
\hline エ & $\begin{array}{l}\text { みんなの日本語第 } 2 \text { 版本冊初級 I 、 } \\
\text { みんなの日本語初級 II }\end{array}$ & $\begin{array}{l}\text { 大家的日本語改訂版初級 I、II } \\
\text { 大家的日本語進階 I、 II }\end{array}$ \\
\hline 才 & 文化中級日本語 I 、 II & 新文化日本語中級 1～4 \\
\hline
\end{tabular}

これらの資料は、日本でも日本語教育の教材として知られ、用いられているが、 本稿では台湾の出版社によって印刷・販売されているものを調査資料として扱う。 詳細は本稿の末尾に掲載する。なお、以下使用例を示寸際には、すべて台湾で出版 されている資料に基づく。これらを調査することで、中国語を母語とする台湾の日本語 学習者が「きく」について、どのように言語知識を得ていくかを確認する。

\section{4. 台湾で使用される日本語教科書における「きく」}

\section{1 語義別に見る「きく」の使用概況}

まず、各教材における「きく」の現われ方を確認しておく。意味別にまとめるが、語 義の認定基準に関して説明する。本稿では、多義語「きく」の語義認定を森山（2012）に 基づいて行う。日本語の大型辞典は語彙量が膨大であり、語義の説明や分類が細かく 行われているが、このことがかえって、日本語学習者、特に初級や中級の学習者に

2 現行の JLPT では語彙レベルは公開されていないが、旧日本語能力試験出題基準レベルに基づい ては、2009年度までの 4 級においての公開されていたレベルと同じ級にあたる。 
とって利用しにくい理由にもなっている。森山(2012) は語彙学習のために編集された ものであるため、「意味のネットワーク」、つまり、語義の派生に重点をおいて記述し、 効率よく語彙の理解と運用力を深めようと寸る方針である。また、「現代では用いられ なくなった用法や、学習者にとってニーズの低い用法」を掲載しない(「はじめに」, p.3) とある。この特徵から、森山 (2012) は上級学習者や日本人の使用にはふさわしいとは 言いがたいが、初・中級学習者にとっては学習の妨げとなる語義解釈や分類の煩雑さ が避けられることで、利用しやすいものと考えられる。

森山(2012)では、「意味ネットワーク」に見る中心義と派生義にそれぞれ番号が 付されている。本稿では語彙の意味派生と学習との関係に触れることはないが、便宜上 その番号を用いて語義を示寸。森山(2012)における「きく」の語義は図 $1{ }^{3}$ に従う。図中 の番号について、同書の説明を一部引用する。なお、以下に語義を提示する際には、 森山(2012)の表し方と異なり、【】を用いて示す。

中心義 :【0】で示した。現代語における語義のうち、中心的で派生の起点となる と考えられる語義である。

一次派生義：中心義から拡張した主要な語彙。【1】【2】のように数字で示した。 二次派生義：意味変化が比較的小さく、独立した派生義とするに及ばないもの で、中心義や一次派生義に属寸る下位の語彙。【0a】1a】のように、 数字に a, b, c のアルファベットを添えて示した。

（p.6、引用内の【】の記号の付加は筆者による）

図 $1 ：$ 「きくの意味ネットワーク図

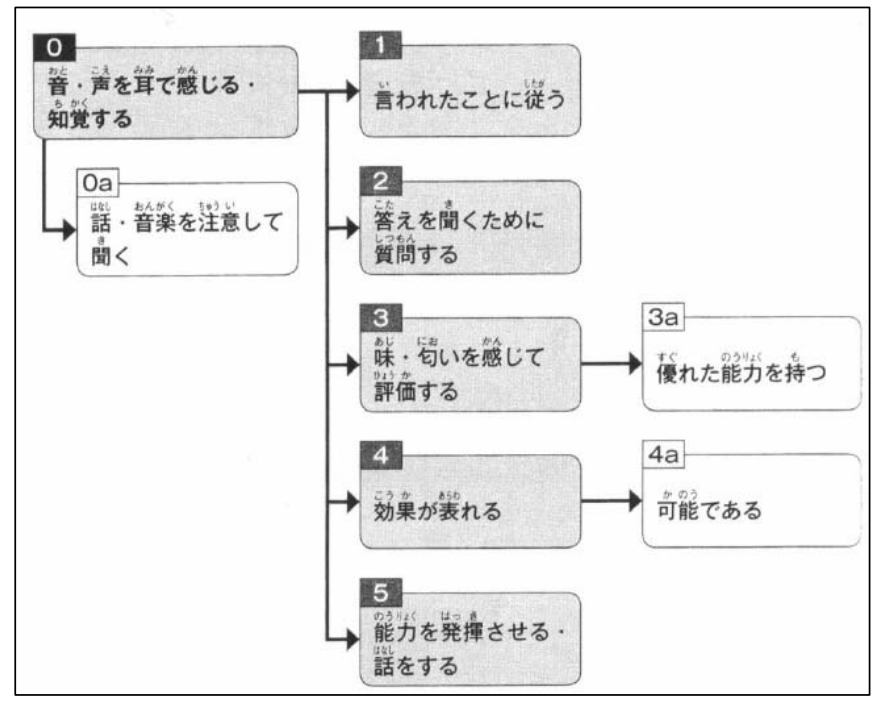

3 『日本語多義語学習辞典』森山 (2012)「きく」の項目 (p.158)による。 
以上の分類に基づき、初・中級教科書における「きく」の使用概況を語義別に見る。 全体の使用状況は表 2 のおりである。

表 2 : 語義別に見る各教科書の「きく」の使用数

語義【0/0a】

\begin{tabular}{|l|l|l|l|l|l|}
\hline \multicolumn{1}{|c|}{ 材 } & ア & イ & ウ & エ & オ \\
\hline 初出課 & vol. 1 L6 & vol. 1 L2 & 基礎 1 L5 & 初級 I L6 & vol. 1 L1 \\
\hline 使用例数 & 18 & 24 & 63 & 17 & 63 \\
\hline
\end{tabular}

語義【1】

\begin{tabular}{|l|l|l|l|l|l|}
\hline 教 材 & ア & イ & ウ & エ & オ \\
\hline 初出課 & & & & & vol. 1 L2 \\
\hline 使用例数 & 0 & 0 & 0 & 0 & 4 \\
\hline
\end{tabular}

語義【2】

\begin{tabular}{|l|l|l|l|l|l|}
\hline \multicolumn{1}{|c|}{ 材 } & ア & イ & ウ & エ & オ \\
\hline 初出課 & vol. 2 L13 & vol. 2 L13 & 基礎 2 L18 & 初級 II L23 & vol. 1 L1 \\
\hline 使用例数 & 17 & 17 & 30 & 13 & 28 \\
\hline
\end{tabular}

語義【4】

\begin{tabular}{|l|l|l|l|l|l|}
\hline 教 材 & ア & イ & ウ & エ & オ \\
\hline 初出課 & vol. 2 L16 & vol. 2 L16 & & & vol. 3 L9 \\
\hline 使用例数 & 1 & 2 & 0 & 0 & 1 \\
\hline
\end{tabular}

音や声を耳で感じる【0】と、注意して聞く【0a】は、いずれの教科書においても ほかの語義より早く提示されており、また出現回数がもっとも多いことがわかる。 日本語教育の立場では、【 $0 / 0 \mathrm{a} 】 の$ 語義は「きく」の語義のうちでも、基本的であり、 早い段階で学習者に習得させたい語義である。語義【1】「言われたことに従う」と判断 できる使用例は中級教科書に見られ、4 例のみである。語義【2】「答えを聞くために 質問する」の導入順は「音声や情報を受け取る」に次いで、初級教科書では 2 冊目の中間、 つまり、初級の中盤からとなっている。また、使用例数が【0/0a】よりやや少ない。 【0/0a】の理解や使用が安定してからの導入と考えられる。語義【4】「効果が表れる」 の使用は【2】と同様に、初級の中間の段階で導入されるが、すべての初級教科書で なく、アとイのみに見られる。森山 (2012) で挙げられている語義【3/3a】「酒を利く」 や「利き手」と、語義【5】「口を利く」などの用法については使用がない。語義の導入順 などに基き、今回調査した 5 種類のテキストに限っていうと、日本語教育の初・中級 段階においては、「きく」の語義は重要性や実用性の視点から以下の図 2 のように表す ことができる。 


\section{図 2 : 教科書に見る「きく」の各語義の重要性}

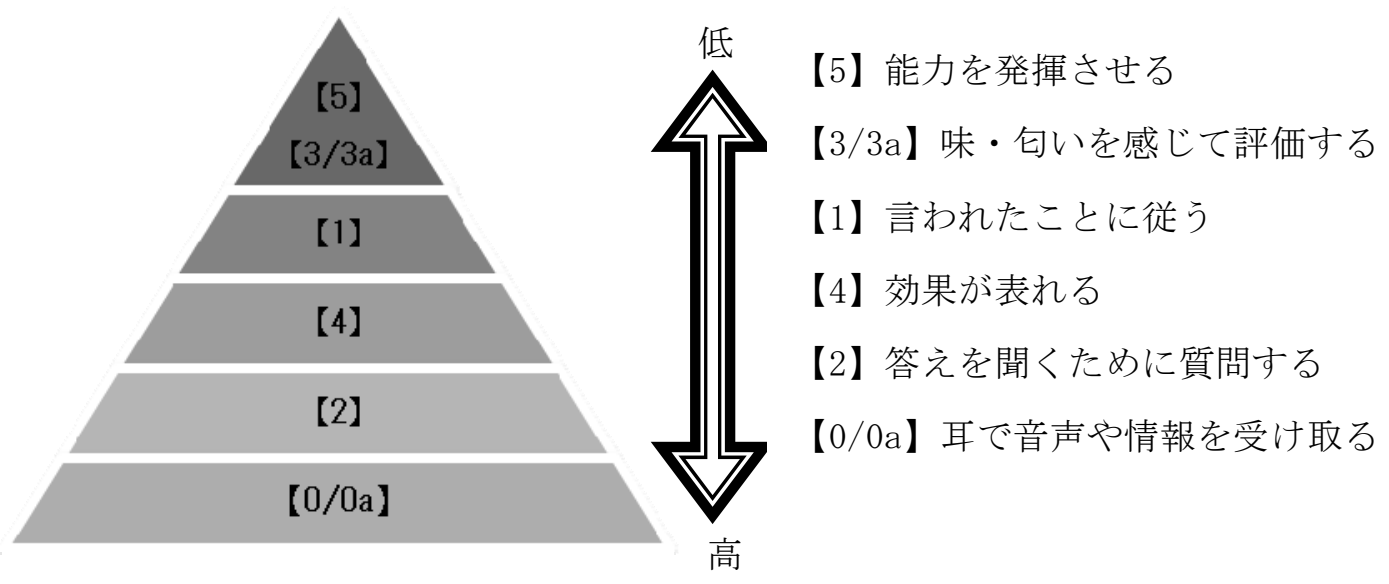

総数 300 余りの用例のうち、ほとんどの用例が単一語義であり、初・中級の段階に おいて、それぞれ語義の重要性や実用性に基づき、教科書に導入されている。しかし、 複数の語義を有すると考えられる文もあり、判断に惑うこともあると予想される。 また、本稿のパイロット調査として、筆者が勤務する教育機関で日本語学習歴 1 年 と 2 年の学習者を対象に、教科書に用いられる「きく」を 20 文取り上げて、それらの 語義を判断してもらうという調査 ${ }^{4}$ を行った。この調査では、「きく」の語義の判断が 間違っているか、戸惑うような用例にパターンが見られた。以下の節ではその理由と パターンを説明・分析したうえで、解決法を考える。

\section{2 曖昧な語義を有する文}

\section{2.1 用例分析}

本稿の調査資料の中で曖昧な語義を有すると考えられる例文と、4.1 で言及した パイロット調査で初・中級の学習者が語義判断を間違えがちな文は、以下の例 (1)〜 (7) である。これらの例文は、初級の後半か、中級の段階で使用され、本文や練習問題に 散在している。なお、日本語を母語としない筆者の判断に間違いがないように、日本語 母語話者、かつ日本語学の研究者に語義の判断・確認を依頼した。その結果を踏まえ、 用例の分析を進める。

4 調查は質問紙形式で、2016 年 6 月と 9 月に、2 回実施した。回答者は全 60 人である。統計学的 に見れば、回答者がわずか 60 人で、信頼できるデータとは言いがたい。本稿では、調查結果を 観察された現象として扱う。なお、質問紙の一部は本稿の未尾に掲載する。 
（1） 来週の遠足でどこへ行きますか／あなたはそのことを聞きましたか。（『ウ』 基礎進階 II 、p.32、練習問題)

（2）ワンさんが来週の進学説明会に（行きますか）聞きましたか。（『ウ』基礎 進階 II 、p.33、練習問題）

（3）さっき課長に聞いたんですが、佐藤さんは今年で会社を (やめる) ですよ。（『ウ』基礎進階 II 、p.45、練習問題）

（4）さっき課長に聞いたんです。（『ウ』基礎進階 II 、p.50、会話本文）

（5）さっき名前を（聞きます $\rightarrow$ ）なのに、忘れてしまいました。（『エ』 進階 II 、p.143、練習問題）

（6）日本に長くいる先韭に聞いた。（『才』vo1.2、p. 29、練習問題）

（7）また、先日友人が行ったので、その人にも話を聞いてみました。（『オ』vol.2、 p.101、練習問題)

初級の段階に見られる「音楽をきく」のような例文では、「きく」は語義【0】としか 解釈できず、学習者が意味の判断に戸惑うことはない。しかし、例 (1)〜 (7) における 「きく」は、「音楽をきく」のように、一つの語義を表すに止まらず、語義【0a】と【2】 と解釈することが可能である。この 2 通りの語義から、比較的自然なほうが選ばれて いると考える。このため、初・中級の学習者はこのような文を理解することに支障が 生じるのである。この問題を解決するために、まず、このような文はなぜ許容されて いるのかについて考える。

「きく」は基本動詞であり、また、概念的にはレベルの高い上位概念である。「情報の 得方」という視点から「きく」を見ると、森山(2012)による語義【0a】は「情報が勝手に 耳に入るもの」であり、【2】は「自分から情報を獲得しに行く」という意味になる。 つまり、【0a】は受動的で、外から入ってくるものであり、【2】は積極的で、自分から 獲得の行為を行うものであると言える。そして、この二つの語義は、「情報を得る」と いう点においては共通しており、同じ上位概念を有することになる。逆に言えば、【0a】 と【2】は「情報獲得」という上位概念の一部であり、「きく」を使うことによって、両方 の意味を表すこともできる。このように、一つの動詞において複数の語義がとれる 状況が存在することになる。このような表現の仕方は日本語を母語としない学習者に とって、必ずしも理解しやすい概念とは言えない。筆者はほかの言語に精通している わけではなく、また、中国語を母語とする学習者以外の人たちを対象に日本語を 教える経験がないため、中国語のみを取り上げることとし、中国語における「きく」の 語義を対照させながらみていく。 
現代中国語口語表現では、語義【0a】と【2】はそれぞれ「聽」と「問」に相当する。 この場合、日本語では一つの動詞によって複数の語義およびその上位概念を表すこと ができるのに対して、中国語では二つの動詞で表現する。さらに遡って、中国語に おける「聽」と「問」の語義を確認する。語義の確認には、台湾中央研究院言語学研究所 によって構築されたコーパス5を使用する。名詞や後置詞などの用法を除き、「聽」と 「問」の動詞用法のみを次に示す。
「聽」：(1) 用耳朵接受聲音。
(2) 聽取。
(3) 服從。
(4) 允許。
(5) 考察。
(6) 治理。
(7) 審理（訴訟案件）。
(8) 商議。
(9) 任憑。（10）等候。
「問」：（1）詢問。
(2) 論難。
(3) 過問。
(4) 審訊（罪犯）。
(5) 責問。
(6) 尋訪。
(7) 饋贈。
(8) 慰問 ; 探望。
（9）舊時訂婚，男方向女方下聘禮。

古典籍を含む資料における 2 語の語義を確認した結果、「聽」と「問」はそれぞれの 系統をなしており、意味が重なることは見られない6。この 2 語は中国語においては、 日本語「きく」のように二つの語義の間に共通する概念が存在しないと言える。中国語 を母語とする日本語学習者は、「きく」の語義【0a】は「聽」に、語義【2】は「問」に、 一対一でそれぞれ当てはめて記憶する学習過程をたどっていることが多い。このため、 例 (1)「来週の遠足でどこへ行くか聞きましたか」のような文における「きく」は、果た して「聽」か「問」のどちらの語義に相当するのかと考えがちで、語義の判断に戸惑う ことになるのである。この場合、指導する側はどのように説明し、問題解決に導けば いいのか。本調査で見られた用例をもとに、動作の積極性に着目し、その解決法に ついて考える。語義判断するのに有効な方法によって、例 (1)〜 (7) は二つのパターン に分けることが可能である。本稿では文脈依存型と共起関係依存型と呼ぶこととし、 以下に説明する。

\section{2.2 パターン $1:$ 文脈依存型}

本稿でいう文脈依存型の文とは、語義が曖昧で、複数の状況が想定可能な場合、 文脈に頼って、ふさわしい状況や語義が選択されることができるものを指す。ただし、

5 台湾中央研究院コーパス「搜詞尋字」(http://words.sinica.edu.tw/sou/sou.html) は現代語のみならず、 『論語』をはじめとする古典籍における語彙の使用例も含まれている。検索日 : 2016 年 10 月 11 日 6 「聽」の意味(7)「審理(訴訟案件)」と「問」の意味(4)「審訊(罪犯)」は、コーパスにおける中国語での 表現は、同じ意味と捉えられる可能性があるため、それらの違いについて、コーパスにおける 実例を挙げて説明する。

「聽」の (7)「審理 (訴訟案件)」の実例として、清・《正字通·耳部》“聽，聽獄，斷也。”が挙げ られている。ここにみる「聽獄」は、「獄を断ずる」、つまり、「裁く」ことを意味する。その一方で、 「問」の（4）「審訊（罪犯）」の実例としては、《紅樓夢》：“後來聽見你兄弟問了死罪”が挙げられ、 「罪を問いただす」という意味である。 
小説資料と異なり、教科書では文が単独に現れることが多く、必ずしも文脈がある とは限らない。よって、本節では文脈依存の文が存在する可能性を指摘し、指導の 仕方として提示する。文脈依存型の文は例 (1)〜 (6)である。その中から 3 例挙げて、 説明する (以下、再掲する)。

（1）来週の遠足でどこへ行きますか／あなたはそのことを聞きましたか。

来週の遠足でどこへ行くか聞きましたか。

この文では、語義【0a】と【2】の両方の語義が想定される。まず、語義【0a】の 状況としては、教師が学生に向けて遠足の場所をアナウンスした後の会話になる。 この場合、遠足の場所という情報が勝手に入ってくるため、【0a】になる。そして、 【2】の状況は、遠足に行くことだけを情報として持っているが、具体的な場所を 知らない学生は、教師に遠足の場所を尋ねて確認するという場合である。自発的、 積極的に情報を得に行くことになるため、【2】になる。いずれの語義も遠足の場所に ついて情報を得ているかどうかを確認することになるが、情報の得方は動作の自発性 や積極性によって異なり、それにより語義が選択される。

次に例 (3) と（5)を見る。

（3）さっき課長に聞いたんですが、佐藤さんは今年で会社を (やめる) ですよ。

つさっき課長に聞いたんですが、佐藤さんは今年で会社をやめるそうですよ。

（5）さっき名前を（聞きますい） なのに、忘れてしまいました。

ヤさっき名前を聞いたのに、忘れてしまいました。

（3）では、【0a】の状況としては、課長から佐藤さんの辞職の情報がもたらされた 場合で、受動的なものである。【2】は、話し手が佐藤さんの今後について課長に確認 した場合となり、佐藤さんが辞めるという情報を獲得しに行っている状況である。 例 (1) と同様に、課長から情報を得ているという結果になるが、得方は受動的なのか 自発的なのかによって、語義の選択が行われることになる。さらに、（5）においても、 【0a】と【2】と両方の語義に解釈することが可能であり、状況次第である。他人から 紹介された場合なら、受動的に情報を得ることとなり、語義【0a】である。自ら積極 的に相手の名前を尋ねる場合も考えられ、【2】となる。

以上に示したように、「きく」の語義【0a】と【2】は上位概念が共通している。 学習者が語義判断を行う際に、場面や状況などの文脈を頼りにして判断することが、 一つの手がかりになると考えられる。 


\subsection{3 パターン 2 : 共起関係依存型}

共起関係は近年、言語教育や辞書作成において重要性が指摘されている。特に基本 語彙であればあるほどコロケーションが豊富であるとされている。「きく」の共起関係 に関する先行研究は小野・他 (2014、2015) があり、「きく」は格により基本義が限定 されることが指摘されている。

共起関係依存というパターンの文は、今回のパイロット調査では 1 例のみである。 この 1 例に見られる「きく」の共起関係について観察する。次のページの例 (7) である (以下、再掲する)。

（7）先日友人が行ったので、その人にも話を聞いてみました。

この文における「きく」の前方共起関係と見る、「人に話を聞く」という型になる。 森田(1979)「きく」の項目7では、以下のように述べられている。

積極的に問い尋ねる行為も「聞く」であり、必ず相手 $(\mathrm{B})$ を設定し、相手の答えを 期待しての言語活動である。(中略)「 $\mathrm{A} カ 3$ B $\mathrm{B}=\mathrm{C}$ 聞く」と相手「 $\mathrm{B}$ 二」を立てるの が特徵。ふつうの「聞く」は「Aガ C ヨ聞く」で、特に Bを立てない。

この説明によると、(7)の「きく」は語義【2】になる。しかし、指導する際に、「Aガ $\mathrm{B}=\mathrm{C}$ 习聞く」の型の文なら、その文における「きく」の語義が【2】である、と指導する ことが適切であろうかと考える。4.2.2 に挙げた例(3)は、「B二聞く」の型であるにも かかわらず、実際に日本語母語話者の判断によると、【0a】と【2】のいずれも解釈 可能ということになる。「相手「Bニ」を立てる」という共起関係のパターンが問い尋ねる 「きく」、ということはかえって学習者の思考を制限してしまうことが考えられる。 そこで、語義判断の一つ手がかりとして、前方の共起関係のみならず、後方の共起 関係にも注目すべきであることを提案する。例(7)に限っていうと、「きく」の後方共起 表現は補助動詞「〜てみる」である。「〜てみる」という表現は、自発的な行動ととるのが 一般的であるため、語義【2】と解釈するほうが自然である。後方共起関係による語義 判断の有効性については、本稿では用例が少ないため、現段階ではすべての文に適用 できるとは言いか䄈る。さらにほかの資料における使用例を調査し、確認する必要が ある。

\section{5. まとめ}

本稿では、実際に教育現場に見られた、中国語を母語とする学習者が多義動詞「きく」 の語義判断に戸惑うという問題をきっかけに、台湾で使用されている教科書における 多義動詞「きく」の使用を調查・分析したものである。使用頻度の高い語義【 $0 / 0 \mathrm{a} 】$ 「耳で音声や情報を受け取る」と、【2】「答えを聞くために質問する」の二つの語義は、

7 森田 (1979)、pp. $177 \sim 179$

論文 14 
日本語において上位概念を共有している一方、中国語では「聽」と「問」の 2 語で表され ており、また、それらの上位概念が共通していない。このため、中国語を母語とする 日本語学習者にとって、多義動詞「きく」の語義を判断することが難しいと推測できる。

以上の問題を解決するために、使用例を文脈依存型と共起関係依存型に分類し、 それぞれのパターンにおける「きく」の動作の自発性と積極性に着目した。文脈依存型 の文では、その動作に自発性と積極性があるかどうかは、文脈によって決まることが 見られ、それに基づき、語義の判断ができる。一方、共起関係依存型の文では、前方 共起のみならず、後方共起表現に着目することも有効であることを提示しておく。 積極性が認められる「〜てみる」という補助動詞が後接する場合、積極性を有する語義 【2】と解釈することが自然である。すわなち、自発性と積極性の有無によって、それ に相応寸る語義を選択寸ることが妥当である。

指導する立場としては、初級後半や中級の段階から、より豊富な選択の仕方を提供 できると考えている。ただし、本稿は教科書のみを調査資料としている。より自然な 日本語における「きく」の語義判断の方法を提供するため、さらに資料のジャンルを 増やし、調查・分析の必要がある。その結果を日本語教育の現場に活用できるように したいと考えており、今後の課題としたい。 


\section{参考文献}

小野正樹他 (2014)「動詞「きく」のコロケーションについて一WEB コーパスと日本語母語話者・上級

日本語学習者の主観的判断から一」『第 5 回日本語学ワークショップ予稿集』

- (2015)「日本語動詞「きく」のコロケーションについて一WEB コーパスと日本語母語

話者・上級日本語学習者の判断から一」『筑波大学留学生センタ一日本語教育論集』30 号

茅本百合子 (2000)「日本語を学習寸る中国語母語話者の漢字の認知：上級者・超上級者の心内辞書

における音韻情報処理」『教育心理学研究』48(3)

邱香霏 (2006) 『日本語の動詞の多義性分析一「きく」を中心に一』高雄第一科技大学応用日本語 学科修士論文

国広 哲弥 (1982) 『意味論の方法』大修館書店

熟見 幸美 (2015)「中国語を母語とする日本語学習者による多義動詞の使用一 $\mathrm{KY}$ コーパスに 見られる使用語義の広がり一」『言語文化論集』36 号, 81-96

中西 泰洋 (2010)「中国語を母語とする日本語学習者の読解教育を考える」『神戸大学留学生 センター紀要』16 号

宮岡 弥生 (2005)「中国語母語話者における日本語習得上の困難点一効果的な敬語教育に関する

考察を中心に一」『広島経済大学論集』第 27 巻第 4 号

森田 良行 (1979) 『基礎日本語一意味と使い方』角川書店

森山＼cjkstart新 (2012) 『日本語多義語学習辞典 動詞編』アルク

山崎誠 (2006)「国立国語研究所の語彙調査の歴史と課題」第 12 回研究会講演資料

\section{調查資料}

スリーエーネットワーク (2003)『みんなの日本語』初級 II (中国語書名：『大家的日本語』進階 I 、 II)、大新書局

スリーエーネットワーク (2015) 『みんなの日本語第 2 版本冊』初級 I (中国語書名 :『大家的日本語 改訂版』初級 I 、 II)、大新書局

日本語教育教材開発委員会(2014)『学ぼう！日本語』初級 I 、II (中国語書名 :『來學日本語』基礎 1 、

基礎 2、基礎進階 1 、基礎進階 2)、尚昂文化

文化外国語専門学校(2003)『(新) 文化初級日本語』I、II (中国語書名 :『新文化日本語初級』1 4)、 大新書局

文化外国語専門学校 (2014)『文化中級日本語』I 、II (中国語書名：『新文化日本語中級』1 4)、

大新書局

文化外国語専門学校(2014)『文化初級日本語テキスト改訂版』I、II (中国語書名 :『文化初級日本語

改訂版』1 4) 、大新書局 


\section{付録資料：パイロット調查の質問紙（一部提示)}

動詞「聞く」的語義調查

本問巻旨在調查各位同學對於動詞「聞く」一字, 在句子中的語義選擇及判斷

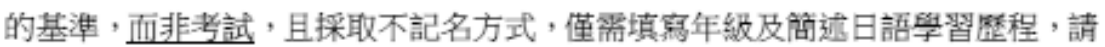
同學安心做答。調查結果將僅用於蔡欣吟本人的研究中。謝謝配合。

年級：

學習日語年数：

請简括日語學習歷程：

請寫出以下句子中出現的動詞「聞く」為何域, 並寫出下該判斷的理由。

1. 図書館の人の説明をよく聞いてください。

意思：

判斷理由：

2. 睱な時は、音楽を聞きます。

意思：

判斷理由：

3.また、先日友人が行ったので、その人にも話を聞いてみ亦した。

意思：

判斷理由：

4. 先生に聞き束から、ちょっと待ってください。

意思 :

判斷理由： 